\title{
Nitrogen and phosphorus effects on blue grama and buffalograss interactions
}

\author{
C.E. RICHARD AND E.F. REDENTE
}

Authors are research associate and professor, Rangeland Ecosystem Science Department, Colorado State University, Ft. Collins 80523 . At the time of research, the first author was graduate research assistant, Rangeland Ecosystem Science Deparment, Colorado State University:

\begin{abstract}
Soil water availability and soil texture appear to influence the relative distribution of blue grama [Bouteloua gracilis (H.B.K.) Lag.] and buffalograss [Buchloe dactyloides (Nutt.) Engelman]. However, nutrient gradients may affect competitive interactions where the species occur together and may influence revegetation efforts in abandoned croplands. A greenhouse experiment was condncted to test whether competition between species was prevalent under relatively nutrient-rich vs. nutrient-poor conditions. Blue grama and buffalograss plants were grown in intraand interspecific pairs under 4 nutrient regimes representing combinations of low and high availabilities of nitrogen $(N)$ and phosphorus (P). Interspecific competition was evident only with high $\mathbf{N}$ and $\mathbf{P}$ availability. Blue grama exhibited greater aboveground biomass, increased tiller production and higher $\mathbf{N}$ and $P$ contents when grown in mixture, compared to monocultures. This was accompanied with a reduction in tiller production and belowground $P$ content in buffalograss grown in mixture. Stolon production in buffalograss was prevalent only with high $P$. Blue grama had greater biomass than buffalograss regardless of nutrient treatment. Bitue grama appears to be more competitive than buffalograss with high nutrient availability and more stress tolerant with low fertility.
\end{abstract}

Key Words: competition, nutrient availability, soil texture, Boutelozia gracilis, Buchloe dactyloides

About 572,000 ha of previously unbroken grasslands in the semi-arid plains of Colorado have been plowed since the mid1970 's (Laycock 1987). These areas are not considered suitable for sustained, non-irrigated cultivation, and are likely to be abandoned (Huszar and Young 1984). The plant communities of the shortgrass steppe of eastern Colorado, dominated by blue grama [Bouteloua gracilis (H.B.K.) Lag.] and/or buffalograss [Buchloe dactyloides (Nutt.) Engelman.] are resistant to natural abiotic

Research was funded in part by the Colorado Agricultural Experiment Station. Authors thank Dr. R. Eouman for the use of laboratory facilities and assistance with tissue analyses. Dr. Terry McLendon for assistance in statistical analyses, and Matt Custer for help in the greenhouse.

Manuscript accepted 10 Dac. 1994. stress. However, recovery from crop abandonment is slow and requires more than 40 years for blue grama and buffalograss communities to reestablish (McGinnies 1983). To hasten the reclamation process, late successional species need to be planted. Depending on the physical and chemical conditions of an abandoned site, competitive interactions can influence the relative dominance of revegetation species. To determine effective seeding mixtures, it is vital to understand how these species interact under different abiotic conditions.

Soil texture and topography appear to influence the relative dominance of blue grama and buffalograss. Blue grama dominates coarser upland sandy and sandy loam soils while buffalograss dominates bottomland, clay loam soils (Schimel et al. 1985). In many areas, buffalograss or blue grama occur as subordinants in communities dominated by the other species. Little is known about how abiotic factors such as soil type and topographic position influence competitive interactions between these species.

Shortgrass steppe soil catenas possess resource gradients, most importantly water and plant nutrients such as nitrogen (N) and phosphorus (P). Abundant evidence suggests that species composition and patterns of dominance change with resource availability (Kirchner 1977; Tilman 1982, 1984; Grime et al. 1987). Experimental resource gradients have been created in the greenhouse to assess changes in competitive responses (Mahmoud and Grime 1976, Fowler 1982, Parrish and Bazzaz 1982). While limited in extrapolation to field conditions, these studies can indicate the potential competitive intensity between species determined by resource overlap (Weldon and Slauson 1986). The objective of this greenhouse experiment was to determine whether the interaction of competition and nutrient availability affects relative growth and nutrient acquisition of blue grama and buffalograss.

\section{Materials and Methods}

The experiment was conducted in a controlled greenhouse environment at Colorado State University in the fall of 1988. Supplemental lighting was provided for 15 hours each day. Photosynthetically active radiation ranged from $177 \mu \mathrm{E} \mathrm{m}^{-2} \mathrm{~s}^{-1}$ on cloudy days to $850 \mu \mathrm{E} \mathrm{m}^{-2} \mathrm{~s}^{-1}$ on sunny days. Average day and night time temperatures were $24.0^{\circ} \mathrm{C}$ and $15.4^{\circ} \mathrm{C}$, respectively. 
Relative humidity ranged from $31 \%$ at night to $43 \%$ during the day,

Cultivars commonly used for revegetation were chosen for the study and included 'Lovington' blue grama and 'Sharp's Improved' buffalograss. Seeds were germinated in commercial potting soil, then rinsed and transferred to $15-\mathrm{cm}$ diameter pots containing $2.500 \mathrm{~g}$ of sterile sand 15 days following planting. Buffalograss burs contain 3 to 7 caryopses, so multiple germinations were clipped to a single sprout. Transplant failure was only $2 \%$ for buffalograss and $4 \%$ for blue grama. Dead seedlings were replaced from flats of germinants for 10 days following transplanting.

The experiment was carried out using the replacement series design of de Wit (1960). Two seedlings were grown per container to achieve blue grama:buffalograss combinations of 2:0, 1:1, and $0: 2$. These 3 treatments were repeated under 4 nutrient regimes: high $\mathrm{N}+$ high $P$; high $\mathrm{N}+$ low $P$; low $\mathrm{N}+$ high $P$; and low $\mathrm{N}+$ low $P$. Hereafter, these nutrient combinations are referred to as treatments $N P, N p, n P$, and $n p$, respectively. High and low concentrations correspond to extreme values of $\mathrm{NH}_{4}^{+}-\mathrm{N}$ and $\mathrm{NO}_{3}^{-}-\mathrm{N}$ plant available $\mathrm{P}\left(\mathrm{NaHCO}_{3}\right.$ extractable) record ed for the Pawnee Grasslands. $1.5 \mathrm{mg} \mathrm{kg}^{-1}$ and $15 \mathrm{mg} \mathrm{kg}^{-1}$ for $\mathrm{N}$, and $0.25 \mathrm{mg} \mathrm{kg}^{-1}$ and $7 \mathrm{mg} \mathrm{kg}^{-1}$ for $\mathrm{P}$ (T.J. Bai, unpublished data). $\mathrm{N}$ and $\mathrm{P}$ were added as $\mathrm{Ca}\left(\mathrm{NO}_{3}\right)_{2}$ and $\mathrm{KH}_{2} \mathrm{PO}_{4}$. Remaining essential plant nutrients were provided in a modified quarter-strength Hoagland's solution. Solutions were added in a volume sufficient to provide nutrients on a $\mathrm{mg} \mathrm{kg}^{-1}$ basis $(200-300 \mathrm{ml})$, and frequent enough to keep soil moist (every 3-6 days). The 12 treatments were replicated 8 times for each of 2 harvest dates in a completely randomized block design.

Plants were harvested at 2 stages of growth. The first harvest coincided with the beginning of buffalograss stolon formation, 45 days after transplanting, and the second harvest occurred at the time of flowering in blue grama, 118 days following transplanting. Plants were removed from the pots, washed, and carefully separated to retain all root biomass. Parameters measured per individual at each harvest were root and shoot biomass and numher of tillers. Aboveground biomass included crowns and tillers. Additional parameters measured at second harvest were number of buffalograss stolon tillers, and nutrient concentration of both root and shoot material. Aboveground and belowground biomass was determined after drying at $60^{\circ} \mathrm{C}$ for 24 hours. Samples were ground in a Wiley mill using a $1.0 \mathrm{~mm}$ mesh screen. Ash-free weights of roots were determined by ashing ground samples in a muffle furnace at $560^{\circ} \mathrm{C}$ for 8 hours, then weighing. Tissue $N$ and $P$ concentrations for roots and shoots were determined using total hjeldahl nitrogen digests followed by colorimetric determination of ammonium and phosphate. $\mathrm{N}$ and $\mathrm{P}$ contents were determined by multiplying biomass by the concentration.

A 3-way analysis of variance $(P=0.05)$ was conducted separately for each species incorporating 3 factors, soil $\mathrm{N}$ level, soil $\mathrm{P}$ level, and species combinations (monoculture vs. interspecific mixtures), to determine significance of treatments and their interactive effects. The following parameters were analyzed for individual plants: above- and belowground biomass, total tillers, crown and stolon tillers, and above- and belowground tissue $\mathrm{N}$ and $P$ concentrations and contents. Competitive effects were indicated using pairu ise comparisons with Student's $t$ tests $(P=0.05)$ between individual plants grown in monoculture and individual plants of the same species grown in mixture. Similar comparisons among individuals of the same species were also made among nutrient treatment combinations. The final pairwise comparison was between harvest dates to determine if interactions between blue grama or buffalograss changed over time. Statistical analyses were calculated using the SAS (1985) General Linear Model procedure. Strong correlations existed between response variable means and their variances. To meet the assumptions of normality, $\log$ transformations were analyzed for measured variables and square root transformations for counted variables. Means and confidence limits from Student's $t$ tests were retransformed for graphical presentation.

\section{Results and Discussion}

Blue grama and buffalograss responded differently to elevated levels of $\mathrm{N}$ and $\mathrm{P}$ at first harvest. Prior to rapid proliferation of stolons and tillers, buffalograss appeared to tolerate low $\mathrm{N}$ levels as evidenced by the lack of above- (Fig. 1a) and belowground (Fig. 1b) biomass response to increased $\mathrm{N}$ concentrations (Table 1). However, both shoot and root biomass of buffalograss increased significantly with addition of $P$ (Table 1). In contrast, root and shoot biomass of blue grama increased with addition of both $\mathrm{N}$ and $\mathrm{P}$, suggesting that both nutrients were limiting blue grama growth when availability was low (Table 1). By the second harvest, both species increased in biomass (Fig. 1c, d) and nutrient content (Fig. 2) in response to $\mathrm{N}$ and $\mathrm{P}$ nutrient additions (Table 2, 3).

Table 1. Analysis of variance for above- and belowground biomass at first harvest. Separate analyses were conducted for each species. $\mathrm{N}=$ Nitrogen, $\mathrm{P}=$ Phosphorus, $\mathrm{Mix}=$ species mixture vs. monoculture.

\begin{tabular}{|c|c|c|c|c|c|c|}
\hline \multirow[b]{2}{*}{ Source } & \multicolumn{3}{|c|}{ Blue grama } & \multicolumn{3}{|c|}{ Buffalograss } \\
\hline & DF & F value & Prob $>F$ & $\mathrm{DF}$ & F value & Prob $>F$ \\
\hline \multicolumn{7}{|c|}{ Aboveground biomass } \\
\hline Block & 3 & 3.29 & 0.0274 & 3 & 3.93 & 0.0137 \\
\hline $\mathbf{N}$ & 1 & 97.43 & 0.0001 & 1 & 3.96 & 0.0522 \\
\hline $\mathbf{P}$ & 1 & 626.17 & 0.0001 & 1 & 326.25 & 0.0001 \\
\hline Mix & 1 & 0.84 & 0.3646 & 1 & 0.03 & 0.8561 \\
\hline$N * P$ & 1 & 23.39 & 0.0001 & 1 & 0.82 & 0.3704 \\
\hline $\mathrm{N} * \mathrm{Mix}$ & 1 & 0.49 & 0.4860 & 1 & 0.06 & 0.8006 \\
\hline $\mathrm{P}^{*} \mathrm{Mix}$ & 1 & 1.17 & 0.2844 & 1 & 0.87 & 0.3556 \\
\hline $\mathrm{N}^{*} \mathrm{P}+\mathrm{Mix}$ & 1 & 0.59 & 0.4471 & 1 & 2.32 & 0.1338 \\
\hline \multicolumn{7}{|c|}{ Belowground biomass } \\
\hline Block & 3 & 2.18 & 0.1009 & 3 & 1.58 & 0.2061 \\
\hline $\mathrm{N}$ & 1 & 29.64 & 0.0001 & 1 & 1.63 & 0.2083 \\
\hline $\mathbf{P}$ & 1 & 157.98 & 0.0001 & 1 & 5.51 & 0.0230 \\
\hline Mix & 1 & 0.11 & 0.7362 & 1 & 0.86 & 0.3592 \\
\hline $\mathrm{N}^{*} \mathrm{P}$ & 1 & 18.98 & 0.0001 & 1 & 1.51 & 0.2244 \\
\hline $\mathrm{N}^{ \pm} \mathrm{Mix}$ & 1 & 1.04 & 0.3130 & 1 & 1.52 & 0.4752 \\
\hline $\mathrm{P} * \mathrm{Mix}$ & 1 & 1.06 & 0.3088 & 1 & 0.04 & 0.8453 \\
\hline$N^{*} P * M i x$ & 1 & 0.26 & 0.6136 & 1 & 0.01 & 0.9422 \\
\hline
\end{tabular}

The tolerance of low $\mathrm{P}$ fertility during the early growth stage of buffalograss plants may be due to larger seed size (Kneebone and Cremer 1955). The lack of response to increased $\mathrm{N}$ may indicate adaptation to habitats normally low in $\mathrm{N}$, suggesting stress tolerance (sensu Grime 1979), and may reflect relatively prolonged utilization of seed reserves. Conversely, blue grama seeds are small caryopses that tend to limit successful germination and establishment in the shortgrass steppe (Carren et al. 1987).

Competitive interactions were not evident at the first harvest regardless of nutrient level. A possible explanation is that growth 

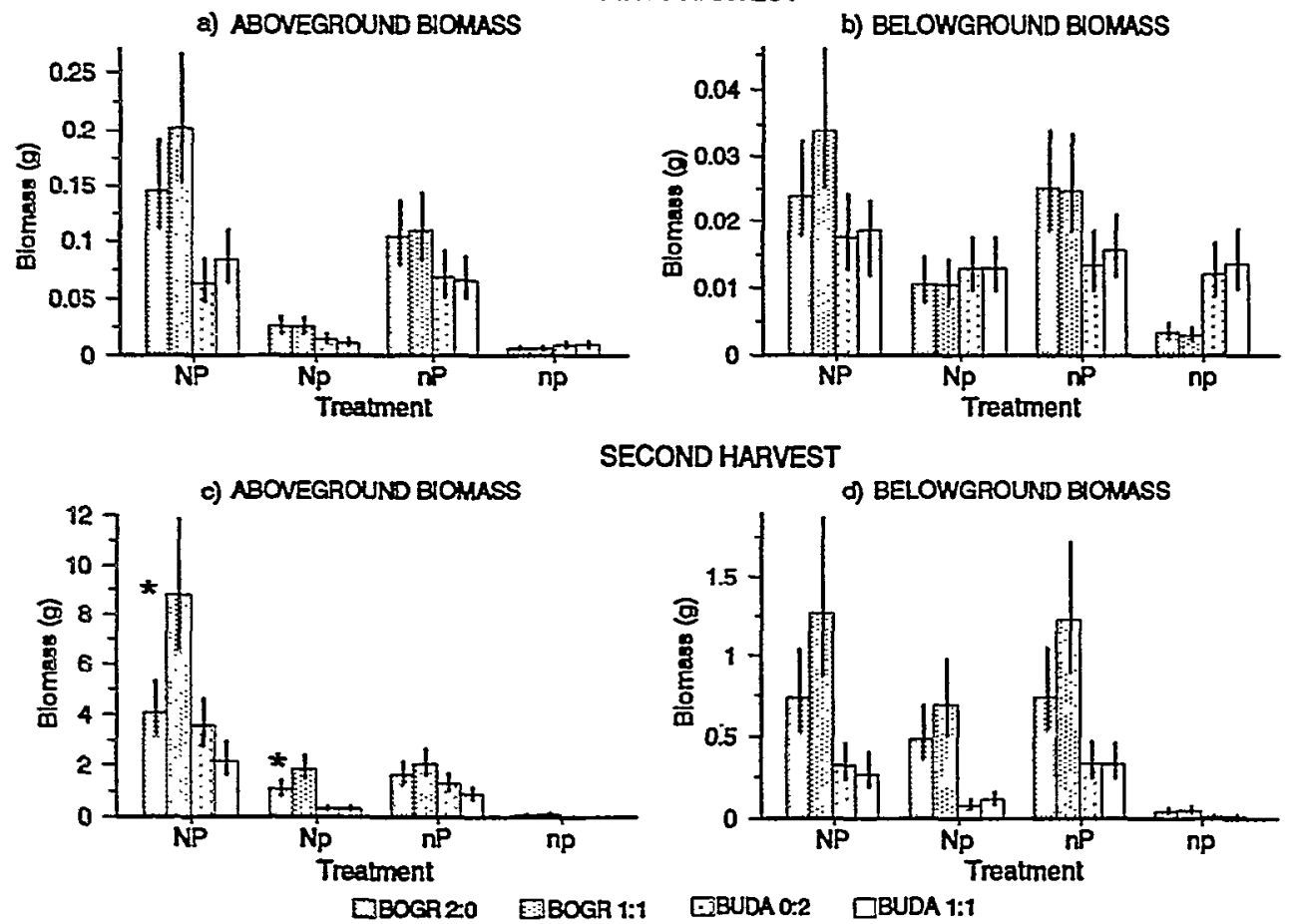

SECOND HARVEST

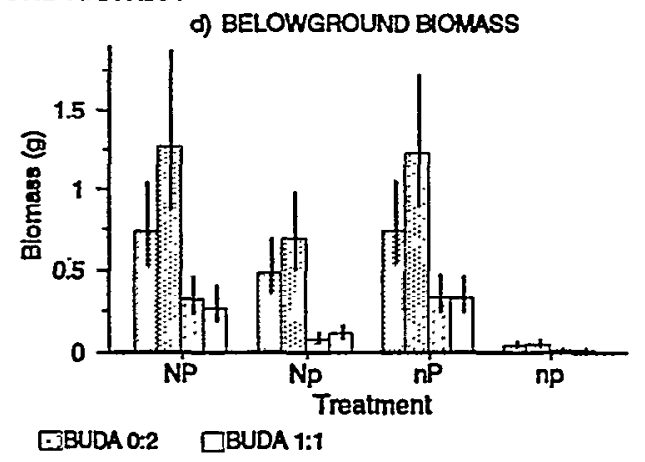

Fig. 1. Individual plant biomass at first and second harrests. Treatment $N P=$ high $N+$ high $P$, treatment $N p=h i g h N+\operatorname{low} P$, treatment $n P=$ low $\mathbf{N}+$ high $P$, and treatment $n p=$ low $N+$ low $P$. BOGR = blue grama, BUDA = buffalograss. Combinations are monoculture of $B O G R$ (2:0), monoculture of BUDA (0:2), and mixture (1:1). Confidence intervals were calculated from Student's $t$ tests $(P=0.05)$. Only significant competitive interactions between individuals within a species grown intra- or interspecifically are indicated with an asterisk.

в) ABOVEGROUND N CONTENT

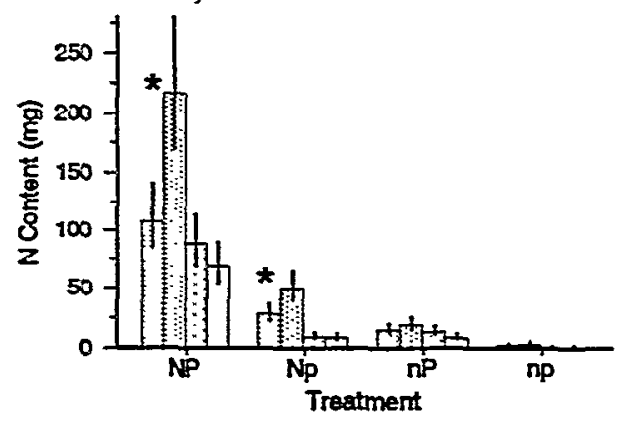

c) ABOVEGROUND P CONTENT

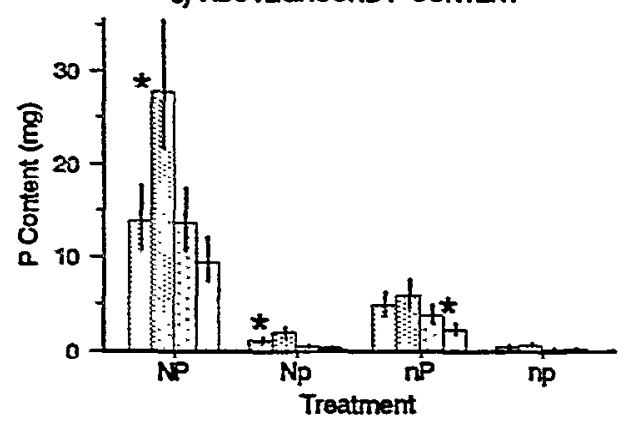

b) BELOWGROUND N CONTENT

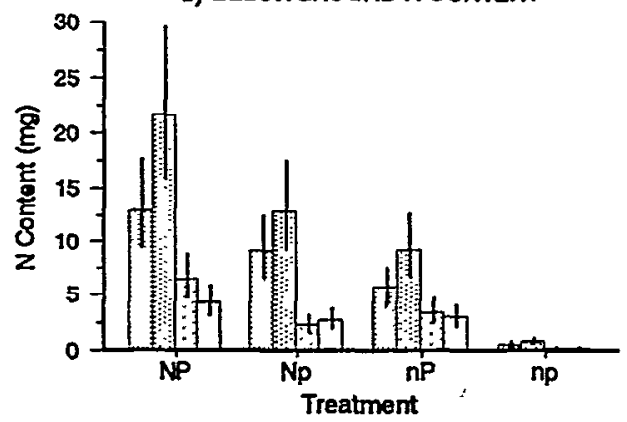

d) BELOWGROUND P CONTENT

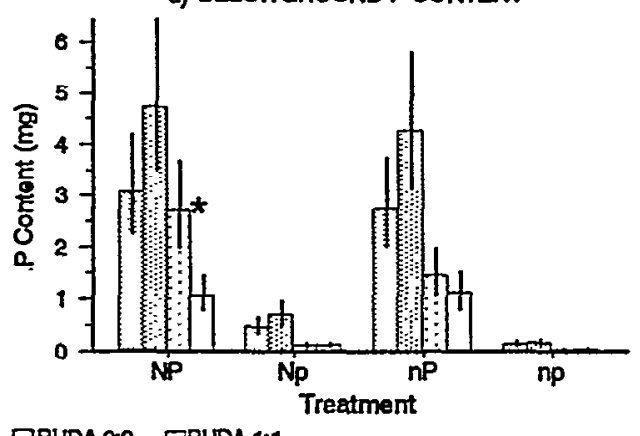

Fig. 2. Total $N$ and $P$ contents of individual plants at second harvest. Treatment $N P=$ high $N+$ high $P$, treatment $N p=$ high $N+\operatorname{low} P$, treatment $n P=\operatorname{low} \mathbf{N}+$ high $P$, and treatment $n p=$ low $\mathbf{N}+$ low $P . B O G R=$ blue grama, BUDA = buffalograss. Confidence intervals were calculated from Student's $t$ tests $(P=0.05)$. Only significant competitive interactions between individuals within a species grown intra- or interspecifically are indicated with an asterisk. 
Table 2. Analysis of rariance for above- and belowground biomass and number of tillers at second harrest. Separate analyses were conducted for each species. $\mathbf{N}=$ Nitrogen, $\mathbf{P}=$ Phosphorus, $\mathbf{M i x}=$ species mixture vs. monoculture.

\begin{tabular}{|c|c|c|c|c|c|c|}
\hline \multirow[b]{2}{*}{ Source } & \multicolumn{3}{|c|}{ Blue stama } & \multicolumn{3}{|c|}{ Buffalograss } \\
\hline & DF & F value & Prob $>F$ & DF & F value & Prob $>F$ \\
\hline \multicolumn{7}{|c|}{ Aboveground biomess } \\
\hline Block & 3 & 2.69 & 0.0561 & 3 & 4.22 & 0.0096 \\
\hline $\mathbf{N}$ & 1 & 501.36 & 0.0001 & 1 & 208.21 & 0.0001 \\
\hline $\mathrm{P}$ & 1 & 653.87 & 0.0001 & 1 & $6 \div 7.91$ & 0.0001 \\
\hline $\operatorname{Mix}$ & 1 & 28.56 & 0.0001 & 1 & 2.42 & 0.1256 \\
\hline$N * P$ & 1 & 57.36 & 0.0001 & 1 & 25.20 & 0.0001 \\
\hline$N=\operatorname{Mix}$ & 1 & 8.63 & 0.0050 & 1 & 0.27 & 0.6034 \\
\hline $\mathrm{P} M \mathrm{Mix}$ & 1 & 0.97 & 0.3304 & 1 & 5.07 & 0.0286 \\
\hline$N=\mathrm{P}: \mathrm{NIx}$ & 1 & 0.50 & $0.4 \$ 42$ & 1 & 0.10 & 0.7572 \\
\hline \multicolumn{7}{|c|}{ Belowground biomiss } \\
\hline Block & 3 & 2.48 & 0.0717 & 3 & 1.42 & 0.2478 \\
\hline $\mathrm{N}$ & 1 & 116.45 & 0.0001 & l & 43.55 & 0.0001 \\
\hline $\mathrm{p}$ & 1 & 227.43 & 0.0001 & 1 & 259.44 & 0.0001 \\
\hline $\operatorname{Mix}$ & 1 & 11.44 & 0.0014 & 1 & 0.07 & 0.7922 \\
\hline$N * P$ & I & 109.31 & 0.0001 & 1 & 54.15 & 0.0001 \\
\hline $\mathrm{N} * \mathrm{Mix}$ & 1 & 0.41 & 0.5115 & 1 & 0.17 & 0.6802 \\
\hline$P * M i x$ & 1 & 1.73 & 0.1947 & 1 & 0.80 & 0.3766 \\
\hline $\mathrm{N}=\mathrm{P}=\mathrm{Mix}$ & 1 & 0.09 & 0.7701 & 1 & 0.90 & 0.3462 \\
\hline \multicolumn{7}{|c|}{ Numbar of tillers } \\
\hline Block & 3 & 1.72 & 0.1740 & 3 & 7.43 & 0.0003 \\
\hline$N$ & 1 & 198.75 & 0.0001 & 1 & 73.04 & 0.0001 \\
\hline $\mathbf{P}$ & 1 & 242.99 & 0.0001 & 1 & 237.26 & 0.0001 \\
\hline $\operatorname{Mix}$ & 1 & 37.14 & 0.0001 & 1 & 3.06 & 0.0861 \\
\hline$N=P$ & 1 & 1.64 & 0.2065 & 1 & 12.99 & 0.0007 \\
\hline $\mathrm{N} \mathrm{Mix}$ & 1 & 21.85 & 0.0001 & 1 & 0.05 & 0.8302 \\
\hline $\mathrm{P} M \mathrm{Mix}$ & 1 & 14.13 & 0.0004 & 1 & 5.43 & 0.0238 \\
\hline $\mathrm{N} \div \mathrm{P}=\mathrm{Mix}$ & 1 & 7.35 & 0.0091 & 1 & 0.25 & 0.6162 \\
\hline
\end{tabular}

rates were low, and. consequently, tiller and root densities were low in the pots. By the second harvest, high nutrient availability appeared to influence competition intraspecifically between blue grama individuals and interspecifically between blue grama and buffalograss. Individuals of blue grama exhibited greater aboveground growth when grown in mixture in treatment NP (Fig. Ic), accompanied with enhanced tiller production (Fig. 3a) and greater $\mathrm{N}$ and $\mathrm{P}$ uptake (Fig. 2a, c). Buffalograss biomass was not significantly decreased (aboveground or belowground), but total tiller production (Fig. 3a) and root P content (Fig. 2d) were significantly reduced when grown in mixrure with blue grama.

Evidence exists for intraspecific competition between individual blue grama plants under high $N$ and low $P$ availability, treatment Np. Blue grama grown in mixture had greater aboveground biomass (Fig. lc; Table 2) and higher aboveground $\mathrm{N}$ and $\mathrm{P}$ contents (Fig. 2a, c; Table 3) than when grown in monoculture. This was not accompanied with a significant reduction in biomass or nutrient uptake in buffalograss, when compared to buffalograss monoculture. This implies that inter-specific competition was not occurring in treatment $\mathrm{Np}$. Rather, biomass of buffalograss was greatly reduced in both mixture and monoculture simply due to inadequate $P$ availability. This reduction in biomass resulted in an increase in the amount of resources available to blue grama when grown in mixture.

Conversely, high $P$ availability possibly intensified competitive interactions by increasing root biomass of both species. Under these conditions, root growth was much more pronounced in blue grama (Fig. 1d). Consequently, reduced $P$ uptake in buffalograss in treatment NP indicated that blue grama was better able to exploit readily available $P$ in solution (Fig. $2 \mathrm{~d}$; Table 3 ). This is
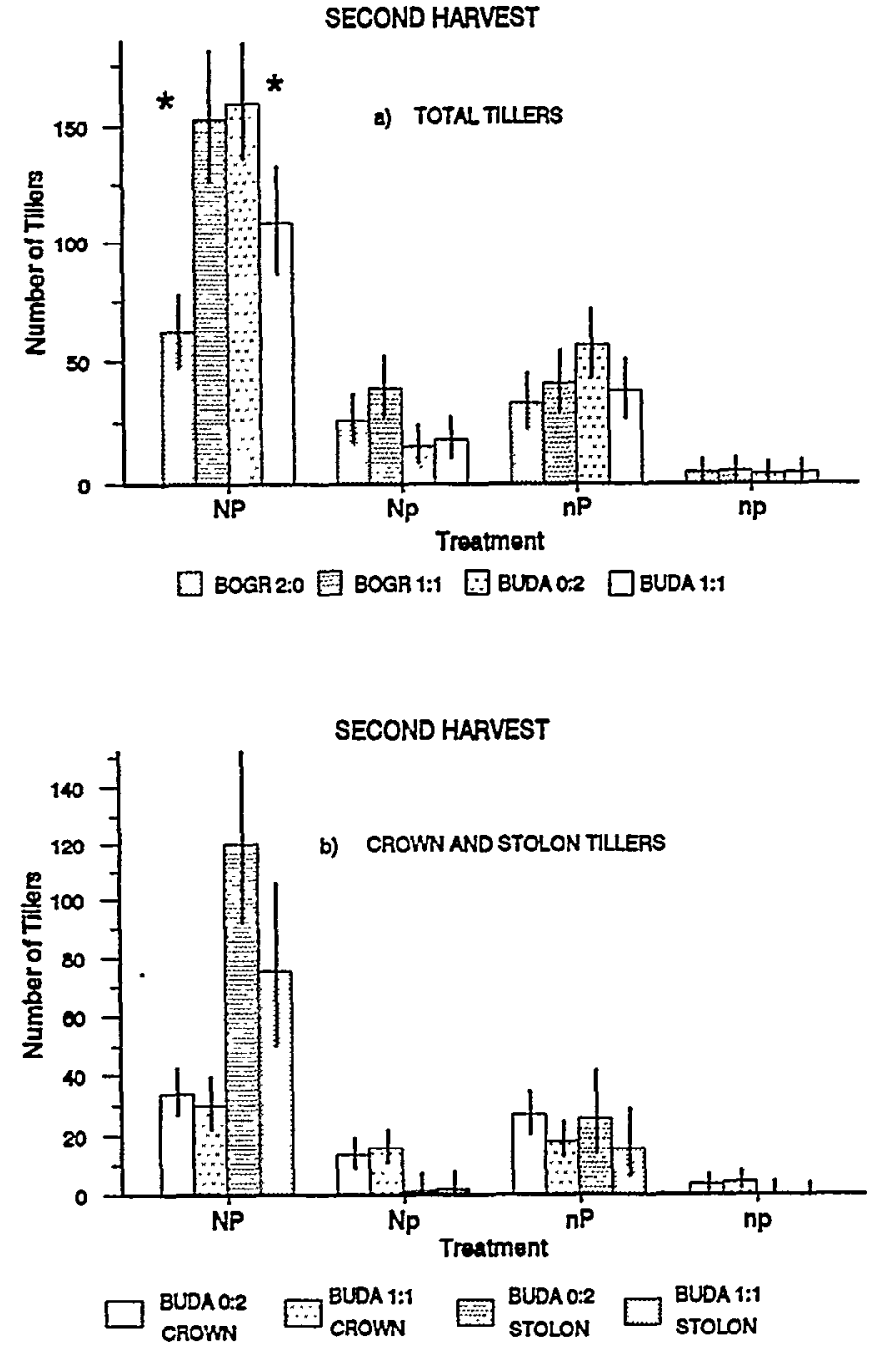

Fig. 3. Number of tillers per plant at second harvest; a) total tillers, and b) crown and stolon tillers of buffalograss. Treatment NP = high $\mathbf{N}+$ high $\mathbf{P}$, treatment $\mathbf{N p}=$ high $\mathbf{N}+$ low $P$, treatment $n \mathbf{P}=$ low $N+$ high $P$, and treatment $n p=$ low $N+$ low $P . B O G R=$ blue grama, BUDA = buffalograss. Confidence intervals were calculated from Student's $t$ tests $(P=\mathbf{0 . 0 5})$. Only significant competitive interactions between individuals within a species grown intra- or interspecifically are indicated with an asterisk.

also expressed in higher tiller numbers for blue grama and lower tiller production for buffalograss in combination compared to their monoculture pairs (Fig. 3a; Table 2). High relative shoot and root growth rates convey a competitive advantage because of greater photosynthetic capability and surface area for absorption (Chapin 1980).

The depletion of $P$ in the sand solution by blue grama may have reduced the amount available for buffalograss stolon tiller production. Lower $P$ content in buffalograss was associated with a reduction in tiller counts (Fig. 3a) but not a significant decrease in biomass (Table 2). A pilot study conducted in the spring of 1988 revealed greater stolon formation in buffalograss when grown in blue grama:buffalograss combinations of $1: 3 \mathrm{vs}$. combinations of 3:1. Plants were grown in a sandy loam soil with $N$ and $P$ fertilization. In the 3:1 mixture, buffalograss plants possessed mostly crown tillers with very few stolons. Combinations of $1: 3$ contained buffalograss plants composed primarily of stolon runners. Even though there were no significant differences in bio- 
Table 3. Analysis of variance for $\mathbf{N}$ and $P$ content at second harvest. Separate analyses were conducted for each species. $\mathrm{N}=$ Nitrogen, $\mathbf{P}=$ Phosphoras, $\mathbf{M I x}=$ species mixture vs. monoculture.

\begin{tabular}{|c|c|c|c|c|c|c|}
\hline \multirow[b]{2}{*}{ Source } & \multicolumn{3}{|c|}{ Blue groma } & \multicolumn{3}{|c|}{ Buffalograss } \\
\hline & DF & Fvalue & Prob $>\mathrm{F}$ & DF & F value & Prob $>F$ \\
\hline \multicolumn{7}{|c|}{ Aboveground $\mathrm{N}$ content } \\
\hline Block & 3 & 2.21 & 0.1165 & 3 & 2.48 & 0.0895 \\
\hline $\mathrm{N}$ & 1 & 980.11 & 0.0001 & 1 & 395.27 & 0.0001 \\
\hline $\mathbf{P}$ & 1 & 439.28 & 0.0001 & 1 & 479.46 & 0.0001 \\
\hline $\operatorname{Mix}$ & 1 & 36.21 & 0.0001 & 1 & 3.36 & 0.0812 \\
\hline$N \approx P$ & 1 & 7.35 & 0.0131 & 1 & 1.01 & 0.3254 \\
\hline$N=\operatorname{Mix}$ & I & 4.59 & 0.0441 & 1 & 0.02 & 0.8785 \\
\hline $\mathrm{P} M \mathrm{Mix}$ & 1 & 0.02 & $0 . \$ 933$ & 1 & 2.27 & 0.1467 \\
\hline$N=P=M i x$ & 1 & 0.59 & 0.4515 & 1 & 0.71 & 0.4078 \\
\hline \multicolumn{7}{|c|}{ Belowground $N$ content } \\
\hline Block & 3 & 2.31 & 0.1059 & 3 & 1.35 & 0.2854 \\
\hline $\mathrm{N}$ & I & 303.14 & 0.0001 & I & 163.49 & 0.0001 \\
\hline $\mathrm{P}$ & 1 & 179.11 & 0.0001 & 1 & 226.15 & 0.0001 \\
\hline $\operatorname{Mix}$ & 1 & 17.34 & 0.0004 & 1 & 0.74 & 0.3985 \\
\hline$N=P$ & 1 & $\$ 5.39$ & 0.0001 & 1 & 71.61 & 0.0001 \\
\hline$N=M i x$ & I & 0.00 & $0.94+3$ & 1 & 0.04 & 0.8361 \\
\hline $\mathrm{p} M \mathrm{Mix}$ & I & 0.69 & 0.4161 & 1 & 2.37 & 0.1388 \\
\hline $\mathrm{N}^{*} \mathrm{P}=\mathrm{Mix}$ & 1 & 0.00 & 0.9787 & 1 & 1.05 & 0.3161 \\
\hline \multicolumn{7}{|c|}{ Aboveground $\mathrm{P}$ content } \\
\hline Block & 3 & I.SI & 0.1755 & 3 & 295 & 0.0561 \\
\hline $\mathrm{N}$ & 1 & 269.02 & 0.0001 & 1 & 78.03 & 0.0001 \\
\hline $\mathbf{P}$ & 1 & 1204.12 & 0.0001 & 1 & 741.18 & 0.0001 \\
\hline $\operatorname{Mix}$ & 1 & 37.58 & 0.0001 & 1 & 7.05 & 0.0148 \\
\hline$N \approx P$ & 1 & 5.93 & 0.0239 & 1 & 20.30 & 0.0002 \\
\hline Nim & 1 & S.34 & 0.0058 & 1 & 0.61 & 0.4429 \\
\hline$P=$ Mix & 1 & 0.12 & 0.7293 & 1 & 2.77 & 0.1107 \\
\hline$N=P=M i x$ & 1 & 0.65 & 0.4294 & 1 & 2.20 & 0.1529 \\
\hline \multicolumn{7}{|c|}{ Belowground $P$ content } \\
\hline Block & 3 & 1.93 & 0.1554 & 3 & 1.32 & 0.2929 \\
\hline $\mathrm{N}$ & 1 & 51.13 & 0.0001 & 1 & 36.59 & 0.0001 \\
\hline $\mathbf{P}$ & 1 & 611.29 & 0.0001 & 1 & 705.08 & 0.0001 \\
\hline $\mathrm{Mix}$ & 1 & 12.98 & 0.0017 & 1 & 4.34 & 0.0496 \\
\hline$N * P$ & 1 & 36.85 & 0.0001 & 1 & 12.70 & 0.0018 \\
\hline $\mathrm{N} \times \mathrm{Min}$ & 1 & 0.20 & 0.6574 & 1 & 4.23 & 0.0522 \\
\hline $\mathrm{P} M \mathrm{Mix}$ & 1 & 0.53 & 0.4745 & 1 & 9.72 & 0.0052 \\
\hline$N \mathrm{~N}=\mathrm{P}=\mathrm{Mix}$ & 1 & 0.27 & 0.6117 & 1 & 0.80 & 0.3816 \\
\hline
\end{tabular}

mass between combinations within a species, competitive interactions were evident by the change in growth form of buffalograss. Buffalograss has been observed to produce a dense mat of tillers when under stress (Tumer 1987). The fact that buffalograss can adopt this more conservative growth form may help to explain its coexistence with blue grama in sites of moderate resource availability (Schimel et al. 1985).

Schmid and Harper (1985) found that clones of wild English daisy (Bellis perennis L.), a compact rosette species, were suppressed when grown with the perennial herb self-heal (Prunella vulgaris L), a loosely aggregated species, at low planting density. Conversely, blue grama, a compact species, reduced growth of buffalograss, a loosely spaced, stoloniferous species, in the small pots. Competitive relationships under greenhouse conditions potentially differed from field studies because buffalograss stolons spilled over the sides of the pots, and consequently, could not root. If stolons had rooted, combined biomass of stolon roots and crown roots may have allowed buffalograss to more effectively exploit resources in the pot, promoting coexistence.

\section{Conclusions}

In the short term, stoloniferous growth may be considered a mechanism of escape from superior competitors, thereby increasing the likelihood of persistence (Eriksson 1986). Schmid (1985) concludes that, given time, species exhibiting stoloniferous growth, such as buffalograss, will not be able to persist in a fairly dense population of the more compact species, such as blue grama, because of their low productivity. Blue grama is not adversely affected by the presence of buffalograss and appears to be more productive as evident in this study and in work reported by Tumer (1987). She also observed a reduction in aboveground biomass in buffalograss when grown with blue grama. Blue grama has been observed to eventually dominate sites once occupied primarily by buffalograss (W.J. McGinnies, personal communication). Perhaps blue grama is better able to exploit resources than buffalograss at high nutrient availability, explaining its greater growth in mixture, and more likely to tolerate low nutrient conditions, reflected in its dominance in infertile habitats. Dominance may occur slowly, however, due to limited lateral spread.

These trends correspond with patterns of composition observed in the shortgrass steppe. Blue grama generally is found in a wide variety of habitats, but predominately in sandier soils that are low in available moisture and nutrients. Buffalograss tends to occur on clay soils with relatively higher moisture and nutrient availability. Bai (1989) discovered a strong correlation between species composition and clay content, substantiating these observations. In addition, he found that dominance by blue grama on clay loams only occurred when these soils were high in $\mathrm{CaCO}_{3}$. Available $\mathrm{P}$ is immobilized in calcareous soils. Perhaps dominance of blue grama in these sites result from its ability to tolerate low $\mathrm{P}$ concentrations.

Footslopes and swales create local areas of resource enrichment that may have an important influence on community structure. Of particular interest is the marked increase in plant available $P$ observed in these locales, while still remaining $\mathrm{N}$-limited (Schimel et al. 1985). It was noted that buffalograss was dominant in footslope positions of the study site with blue grama occurring as a subordinate species. Buffalograss appears to tolerate low $\mathrm{N}$ levels while still capitalizing on available $\mathrm{P}$, as evident in the greenhouse. Perhaps buffalograss has adopted particular strategies that enable it to rapidly utilize available $\mathbf{P}$ for stolon production, therefore increasing its ability to capture open space. Given time, however, blue grama may come to dominate these sites, if indeed it exhibits superior ability to exploit resources.

This study supports the concept that competition occurs between species where nutrient availability is high, as indicated by the marked increase in blue grama growth and nutrient acquisition when grown interspecifically in high $P$ treatments, and the associated decrease in tiller production and $\mathrm{P}$ content in buffalograss. Cultivars used in this study may not reflect natural populations. Results discussed herein, however, may be applicable to revegetated stands of blue grama and buffalograss. Field studies need to be conducted to determine whether nutrient availability influences biotic interactions within topographic sequences, paying particular attention to growth form and density. 


\section{Literature Cited}

Bai, T.J. 1989. Association of Bouteloua gracilis and Buchloe dactyloides. Ph.D. Diss., Colorado State Univ., Fort Collins, Colo.

Carren, C.J., A.M. Wilson, R.L. Cuany, and G.L. Thor. 1987. Caryopsis weight and planting depth of blue grama. I. Morphology, emergence, and seedling growth. J. Range Manage. 40:207-211.

Chapin, F.S. 1980. The mineral nutrition of wild plants. Ann. Rev. Ecol. Syst. 11:233-260.

De Wit, C.T. 1960. On competition. Versl. Landbk. Onderz. No. 66.8.

Eriksson, 0.1986 . Mobility and space capture in the stoloniferous plant Potentilla anserina. Oikos 46:82-87.

Fowler, N. 1982. Competition and coexistence in a North Carolina grassland. M. Mixture of component species. J. Ecol. 70:77-90.

Grime, J.P. 1979. Plant strategies and vegetative processes. John Wiley and Sons. N.Y.

Grime, J.P., J.M. Mackey, S.H. Hillier, and D.J. Read. 1987. Floristic diversity in a model system using experimental microcosms. Nature $328: 420-422$.

Buszer, P.C., and J.E. Young. 1984. Why the great Colorado plowout. J. Soil Water Conserv. 39:232-234.

Kirchner, T.P. 1977. The effects of resource enrichment on the diversity of plants and arthropods in a shortgrass prairie. Ecol. 58:1334-1344.

Kneebane, W.R., and C.L. Cremer. 1955. The relationship of seed size to seedling vigor in some native grass species. Agron. J. 47:472-477.

Laycock, W.A. 1987. History of grassland plowing and grass planting on the Great Plains, p.3-S. In: Impacts of the Conservation Reserve Program in the Great Plains. Rochy Mountain Forest and Range Exp. Sta. USDA For. Serv. Gen. Tech. Rep. RM-158. Fort Collins, Colo.
Mahmoud, A., and J.P. Grime. 1976. An analysis of competitive ability in three perennial grasses. New Phytol. 77:431-435.

McGinnies, W.J. 1983. Difficulty of reestablishing perennial grasses on plowed lands in eastern Colorado. Rangelands 5:64.

Parrish, J.A., and F.A. Bazzaz. 1982. Responses of plants from three successional communities to a nutrient gradient. J. Ecol. 70:233-248.

SAS. 1985. User's Guide: Statistics, Version 5. SAS Institute, Cary, N.C.

Schimel, D., M.A. Stillwell, and R.G. Woodmansee. 1985. Biogeochemistry of $C, N$, and $P$ in a soil catena of the shortgrass steppe. Ecol. 66:276-282.

Schmid, B. 1985. Clonal growth in grassland perennials. II. Growth form and fine-scale colonizing ability. J. Ecol. 73:809-818.

Schmid, B., and J.L. Harper. 1985. Clonal growth in grassland perennials. I. Density and pattern-dependent competition between plants with different growth forms. J. Ecol. 73:793-808.

Tilman, D. 1982. Resource competition and community structure. Princeton Univ. Press, Princeton, R.I.

Tilman, D. 1984. Plant dominance along an experimental nutrient gradient. Ecol. 65:1445-1453.

Turner, S.J. 1987. Competition and coexistence between two $C_{4}$ grasses of the shortgrass steppe. Ph.D. Diss. Colorado State Univ., Fort Collins, Colo.

Weldon, C.W., and W.L. Slauson. 1986. The intensity of competition versus its importance: an overlooked distinction and some implications. Quart. Rev. Biol. 61:23-44. 